\title{
Identification and Quantification of Allelochemicals from Selected Sweet Potato (Ipomoea batatas (L.) Lam.) Cultivars
}

\author{
Bhawna Soni, Te-Ming Paul Tseng, Ziming Yue \\ Department of Plant and Soil Sciences, Mississippi State University, Mississippi State, MS, USA \\ Email:t.tseng@msstate.edu,bhawnasoni23@gmail.com,zy101@msstate.edu
}

How to cite this paper: Soni, B., Tseng, T.-M.P. and Yue, Z.M. (2019) Identification and Quantification of Allelochemicals from Selected Sweet Potato (Ipomoea batatas (L.) Lam.) Cultivars. American Journal of Plant Sciences, 10, 2354-2365.

https://doi.org/10.4236/ajps.2019.1012163

Received: November 2, 2019

Accepted: December 28, 2019

Published: December 31, 2019

Copyright $\odot 2019$ by author(s) and Scientific Research Publishing Inc. This work is licensed under the Creative Commons Attribution International License (CC BY 4.0).

http://creativecommons.org/licenses/by/4.0/

\begin{abstract}
Allelopathic compounds have the potential to inhibit the growth and development of other organisms in a diverse manner ranging from shifting nutrients and enhancing their growth to inflicting diseases. In addition, these compounds influence seedling growth and seed germination of various crops. The goal of this study was to identify and quantify different allelochemicals in various sweet potato cultivars through high-performance liquid chromatography techniques. Selected sweet potato slips (weight: $2.0-2.5$ grams/slip) were propagated in separate glass tubes filled with $10.0 \mathrm{~mL}$ distilled water. Water extract from each glass tube was collected after 2, 4, and 6 weeks after transplanting (WAP) to identify and quantify allelochemical compounds by comparing their peaks with the retention time of standards. Results show that the concentration of allelochemicals in water extract was increased from 2 to 4 WAP but remained constant in the sixth week. Quantitative analysis revealed that the amount of chlorogenic acid was higher in all sweet potato cultivars compared to other allelochemicals. Some sweet potato cultivars, A5 and A39, exhibited higher allelopathy (18.28 - $19.37 \mathrm{ppm} / \mathrm{slip})$ and reduced the height and biomass of Palmer amaranth the most due to the presence of increased concentration of combined allelochemicals, while other cultivars produced lesser allelochemicals $(10.90 \mathrm{ppm} / \mathrm{slip})$ and did not reduce the growth of the weed species. Allelopathic sweet potato cultivars high in chlorogenic acid production can effectively suppress Palmer amaranth with minimal dependence on chemicals to manage weeds and harmful pests under sustainable agricultural system.
\end{abstract}

\section{Keywords}

Sweet Potato (Ipomoea batatas (L.) Lam.), Allelochemicals, High Performance Liquid Chromatography, Seedling Growth, Retention Time 


\section{Introduction}

Sweet potato is one of the most nutritious vegetables and is grown and consumed in many countries around the world. It is also used as an animal feed and as a source of many other beneficial products [1]. In Mississippi, sweet potato is grown in more than 20,000 acres each year, primarily in the Northern Mississippi, with its most substantial acreage centered around the town of Vardaman [2] [3]. Vardaman has an extended record of producing high-quality sweet potato and is also known as the Sweet Potato Capital of the World [2]. In Mississippi, 29,000 acres of sweet potato were harvested across 89 farms, with a production value of \$123 million in 2017 [4]. It is the second-largest sweet potato producing State in the United States after North Carolina. Regrettably, the majority of the sweet potato farms in Mississippi are exposed to problematic weeds that cause substantial yield reduction [5] [6]. Major weeds in sweet potato are yellow nutsedge, purple nutsedge, goosegrass, common cocklebur, redroot pigweed, and Palmer amaranth [7] [8]. Among these weeds, yellow nutsedge and Palmer amaranth are the most troublesome [8] [9]. Yield reduction of up to $81 \%$ was reported with season-long interference of Palmer amaranth in sweet potato [10], while yellow nutsedge at a density of 90 shoot $/ \mathrm{m}^{2}$, resulted in a predicted yield loss of up to $96 \%$ [5] [11]. Moreover, a yield loss of up to $90 \%$ occurs if weeds are not controlled during the initial growing period [6].

Weed interference in sweet potato production is becoming a challenging task due to limited chemical options. In Mississippi, registered herbicides for sweet potato include clomazone, flumioxazin, and S-metolachlor for nutsedge and Palmer amaranth control. Application of clomazone does not adequately control Palmer amaranth [12]; however, flumioxazin provides excellent control of Palmer amaranth, but not of nutsedges [13]. S-metolachlor is effective on yellow nutsedge and Palmer amaranth, however, it also causes significant injury on sweet potatoes, resulting in storage root yield reduction, and decreased storage root quality [5]. Moreover, post-emergence control of weeds is limited to only row middles and fails to control weeds within the planted rows. To overcome these herbicide limitations and enhance sweet potato quality and yield for Mississippi growers, there is a distinct need to find an alternative weed control strategy that can efficiently reduce the weed burden around the crop, and at the same time, protect the yield and quality of storage roots. One of the promising weed control approaches is the utilization of weed suppressive ability that is already present in crop cultivars, known as allelopathy.

Allelopathy is a natural phenomenon where the secondary metabolites produced by one plant species inhibit the growth and development of neighboring species [14]. Several researchers have shown the use of different allelopathic crop cultivars, including rice, wheat, sunflower, and canola, in weed management [15] [16] [17] [18]. Although there are not many reports on the allelopathic property of sweet potato, a few studies have confirmed that sweet potato does suppress the growth of weeds, including alfalfa, and yellow and purple nutsedge; 
however, the specific allelochemicals in sweet potato responsible for weed suppression is unknown [19]. A greenhouse study that looked at the allelopathic effects of sweet potato on yellow nutsedge reported a reduction in yellow nutsedge biomass by $46 \%$ when grown in soil from sweet potato field plots [19]. A similar study showed that a $50 \%$ aqueous methanol extract (concentration equivalent to $2.5 \mathrm{mg} / \mathrm{mL}$ ) of regal sweet potato was highly effective in inhibiting the root growth of yellow nutsedge, while at $10 \mathrm{mg} / \mathrm{mL}$ the root growth was almost entirely inhibited. In terms of weed seed germination, the extract of Regal sweet potato $(10 \mathrm{mg} / \mathrm{mL})$ reduced the germination of alfalfa seeds by $55 \%$, while the extract of SC $1149-19(10 \mathrm{mg} / \mathrm{mL})$ resulted in a $94 \%$ reduction in germination [19]. Another study reported that a $26 \mathrm{mg} / \mathrm{mL}$ methanol extract of sweet potato root was able to inhibit redroot pigweed germination by $50 \%$ [20]. These results suggest that the root periderm tissues of sweet potato acts as a potential source of allelochemicals and constantly produced with the growth of sweet potato flashy roots [21].

The availability of allelopathic crops can help control weeds season long, reduce the repetitive application of herbicides, and prevent further evolution of herbicide-resistant weeds. Moreover, this naturally occurring phenomenon of allelopathy can be used as a biological weed suppression strategy or as a source of new selective weed control mediators [19]. At ambient atmospheric conditions, these allelochemical compounds are secreted into the environment through the processes of decomposition, leaching, volatilization, and root exudation, thus inhibiting the development of neighboring plant species [22] [23].

In the past, researchers have conducted HPLC analysis to determine the allelopathic potential of solvent extracts (aqueous, methanol, ethyl acetate, ethanol, butanol, and hexane) from three different colored sweet potato cultivars by plant parts (leaf, stem, and root) [17] [24]. The concentration and inhibitory effects of coumarin, trans-cinnamic acid, o-coumaric acid, p-coumaric acid, caffeic acid, and chlorogenic acid were determined in various solvent fractions. It was found that the degree of inhibition by each cultivar was increased with increasing extract concentration from 50\% - 100\%. In all the fractions, 61.9 $\mathrm{mg} / 100 \mathrm{~g}$ of chlorogenic acid was detected as the highest component, followed by caffeic acid at $33.5 \mathrm{mg} / 100 \mathrm{~g}$, and trans-cinnamic acid at $20.9 \mathrm{mg} / 100 \mathrm{~g}$ [24] [25]. The study reported that the leaf extracts reduced the root length of alfalfa by $96 \%$, while the stem and root extracts reduced root lengths by $87 \%$ and $85 \%$, respectively [24]. Therefore, the goal of our study was to identify and quantify the all elocompounds using HPLC chromatographic method in sweet potato associated with weed suppression.

\section{Experimental Section}

\subsection{Materials}

A total of 10 sweet potato cultivars were selected from our previous allelopathy screening against Palmer amaranth (Caputo et al., 2018). All sweet potato geno- 
types were obtained from Pontotoc Ridge-Flatwoods Branch Experiment Station, Mississippi State University, Pontotoc, MS. Sweet potato slips of selected cultivars were collected from the greenhouse located in Dorman Hall, Plant and Soil Science Department, Mississippi State University, MS. Reagents used in this study were purchased from commercial sources and used as received without further purification. The following chemicals were purchased from Fisher Scientific and Sigma-Aldrich, USA: chlorogenic acid, caffeic acid, trans-cinnamic acid, coumarin, and hydroxycinnamic acid, acetonitrile, ethyl acetate, methanol, acetone, and glass tubes $(20 \mathrm{~mL})$. All standard solutions of different concentrations were prepared in HPLC grade methanol.

\subsection{Methods}

\subsubsection{Sample Preparation for Chemical Extraction in Water}

Table 1 represents the selected sweet potato cultivars used in this study with their name, source, and other related information. In order to extract allelochemicals from water, sweet potato slips, approximately 2.0 to 2.5 grams of weight with 4 - 5 nodes, were cut and placed in separate glass tubes filled with 10 $\mathrm{mL}$ distilled water (DI-water). Glass tubes were marked to indicate the DI-water level and covered with parafilm to prevent the solvent evaporation. All tubes were covered with aluminum foil and kept inside a growth chamber (Percival Scientific PS-0349, $\mathrm{T}=24^{\circ} \mathrm{C}, \mathrm{RH}=55 \%$ ). All experiments were conducted in 2018 in the Weed Physiology Laboratory at Mississippi State University, Mississippi State, and repeated twice with three replicates and analyzed quantitatively at 2,4 , and 6 weeks after transplanting (WAP).

\subsubsection{Preparation of Standards for Calibration}

Standard solutions of chlorogenic acid, caffeic acid, trans-cinnamic, coumarin, and hydroxycinnamic acid (Figure 1) were prepared at different concentrations

Table 1. Selected sweet potato cultivars for experimental analysis.

\begin{tabular}{cccccc}
\hline Cultivar & Name & ID Number & Source & Origin & Replicate \\
\hline A5 & Heartogold & $\begin{array}{c}\text { PI 566631 01 } \\
\text { IV }\end{array}$ & USDA, ARS, PGRCU, Griffin, GA & LA & 3 \\
A17 & Centennial & & Louisiana State University & LA & 3 \\
A23 & Covington (new) & $\# 1 \mathrm{M}$ & North Carolina State University & NC & 3 \\
A24 & Hatteras (new) & $\# 4 M$ & North Carolina State University & NC & 3 \\
A31 & Orleans & Orleans-7 & LSU virus tested & LA & 3 \\
A36 & Vardaman & PI566662 & USDA, ARS, PGRCU, Griffin, GA & MS & 3 \\
A37 & Morada, Sombica & PI50831 & USDA, ARS, PGRCU, Griffin, GA & Venezuela & 3 \\
A38 & Morado & PI 538289 & USDA, ARS, PGRCU, Griffin, GA & Peru & 3 \\
A39 & 529 & PI 538306 & USDA, ARS, PGRCU, Griffin, GA & Guatemala & 3 \\
A43 & Spokes Purple & & Vance Farms, Chickasaw, MS & NC & 3 \\
Total = 30 Samples & & & & \\
\hline
\end{tabular}


of $100,50,25,10,5.0$, and $2.0 \mathrm{ppm}$ to obtain the calibration curve for each reference. All analyses were conducted in triplicates.

\subsubsection{HPLC Analysis of Extracted Water Samples}

Water samples $(\sim 2.0 \mathrm{~mL})$ extracted at 2, 4 and 6 WAP were collected and analyzed in HPLC (Hewlett Packard-Agilent 1100 series) using the ultraviolet detector and C18 column (CAPCELL PAK SG120 $(4.6 \times 250 \mathrm{~mm})$ at $30^{\circ} \mathrm{C}$ temperature. Deionized water and methanol (solvent gradient system) were used as an eluent at a flow rate of $0.6 \mathrm{~mL} / \mathrm{min}$, and the run lasted for $30 \mathrm{~min}$. Quantification of all the compounds was carried out by comparing the peak integration values with chromatograms of known standards and presented in parts per million/gram slip.

\subsubsection{Statistical Analysis}

The experimental design was completely randomized, and data were pooled across runs. Data were subjected to analysis of variance using PROC GLM (SAS version 9.4, SAS Institute Inc., Cary, NC 27513, USA), and mean values were separated using Fisher's protected LSD at an alpha level of less than or equal to 0.05. The principal component analysis of JMP 13 (SAS Institute Inc., Cary, NC 27513, USA) was used to visualize correlations among the original variables, and between the variables and components.

\section{Results and Discussion}

The growth of sweet potato slips in DI-water after the second, fourth, and sixth weeks after transplanting (WAP) is presented in Figure 2. The concentration of the extracted allelochemicals increased as the growth of root length increased from 2 to 4 WAP but did not change at 6 WAP. The mode of action of these allelochemicals is involved in the inhibition and alteration of plant growth and may be selective in their responses [26]; this selectivity varies among cultivars.

Quantitative analyses were conducted using HPLC for five different allelochemicals shown in Figure 3. The presence of phenolic acids in water extract is known to inhibit the protein and hormone biosynthesis [27], and change the<smiles>O=c1ccc2ccccc2o1</smiles>

Coumarin<smiles>O=C(O)/C=C/c1ccccc1</smiles>

Trans-Cinnamic Acid<smiles>O=C(O)/C=C/c1ccc(O)cc1</smiles>

Hydroxycinnamic Acid<smiles>O=C(O)/C=C/c1ccc(O)c(O)c1</smiles>

Caffeic Acid<smiles>O=C(/C=C/c1ccc(O)c(O)c1)OC1CC(O)(C(=O)O)C[C@@H](O)[C@H]1O</smiles>

Figure 1. Chemical structure of selected compounds involved in allelopathy. 
ultrastructural components of cells, cell division [28], ion uptake [29], chlorophyll biosynthesis [30], and cell membrane stability [31]. Additionally, a potential suppressive effect of secondary metabolites other than phenolics could not be excluded; flavonoids and terpenoids extracted from sunflower have significant suppressive ability against plants [32].

Figure 3 shows the total and individual allelochemical concentrations produced by each of the ten sweet potato cultivars $(\mathrm{p}<0.0001)$. All cultivars were differentiated into allelopathic and non-allelopathic biotypes according to the amount of allelochemical extracted in water at 2 and 4 WAP. Cultivars 39 and 5 demonstrated higher amounts of total allelochemicals, especially chlorogenic acid, and trans-cinnamic acid. Chlorogenic and caffeic acid was present in all cultivars; however, hydroxycinnamic acid, trans-cinnamic acid, and coumarin were distributed randomly. This variation in allelochemical concentration among all cultivars may be due to their origin and environmental conditions; for instance, cultivars 5 and 39 obtained from the USA (Louisana) and Guatemala are potentially allelopathic biotypes, which may have adapted much better conditions than other sweet potato cultivars. However, cultivars 17 (Louisiana), 38 (Georgia), and 43 (Mississippi) were obtained from different parts of the USA and showed intermediate concentration of allelochemicals. These results express an agreement with our previous study (Caputo et al., 2018) related to the weed suppressive ability against palmer amaranth conducted in the greenhouse (Table 2).

Cultivars 5 and 39 performed their best by reducing palmer amaranth biomass by $80 \%$, and height by $39 \%$. Thus, these two cultivars were identified to be most allelopathic, with an average weed suppressive potential of $63 \%$. Cultivars 36 and 37 , on the other hand, were found to be the least allelopathic with a common
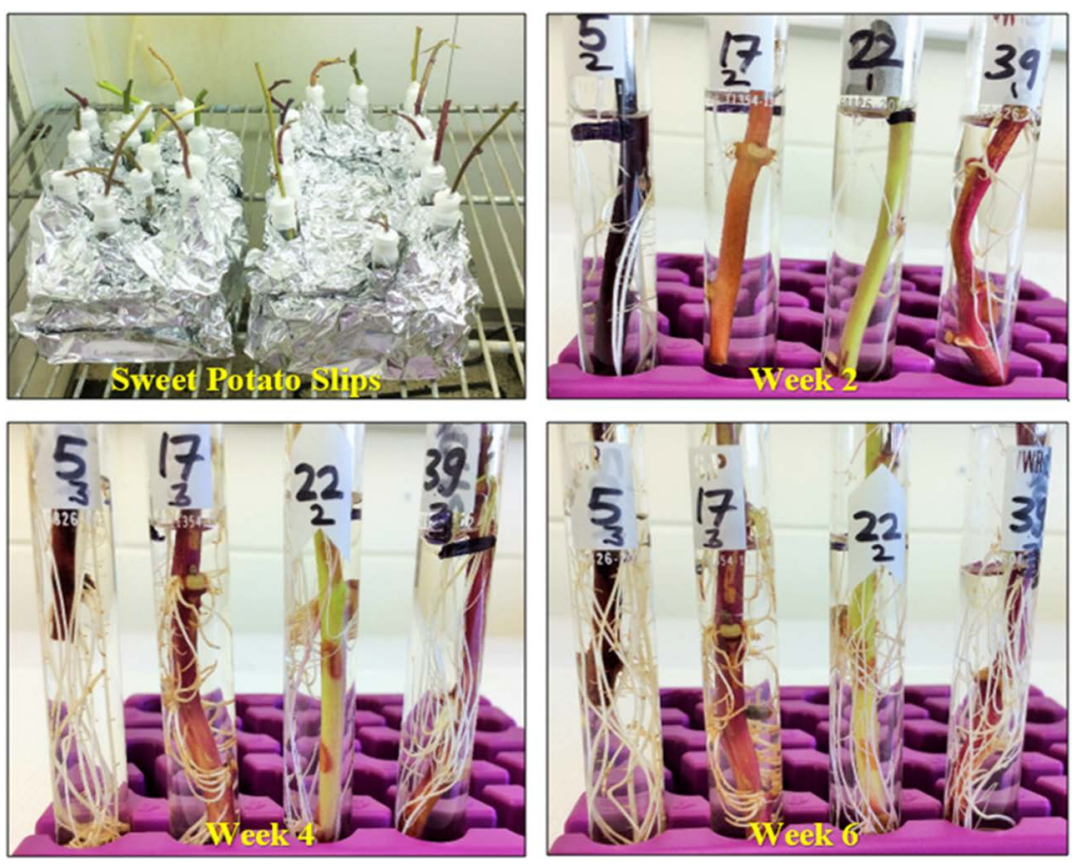

Figure 2. Sweet potato slips growth in distilled water. 


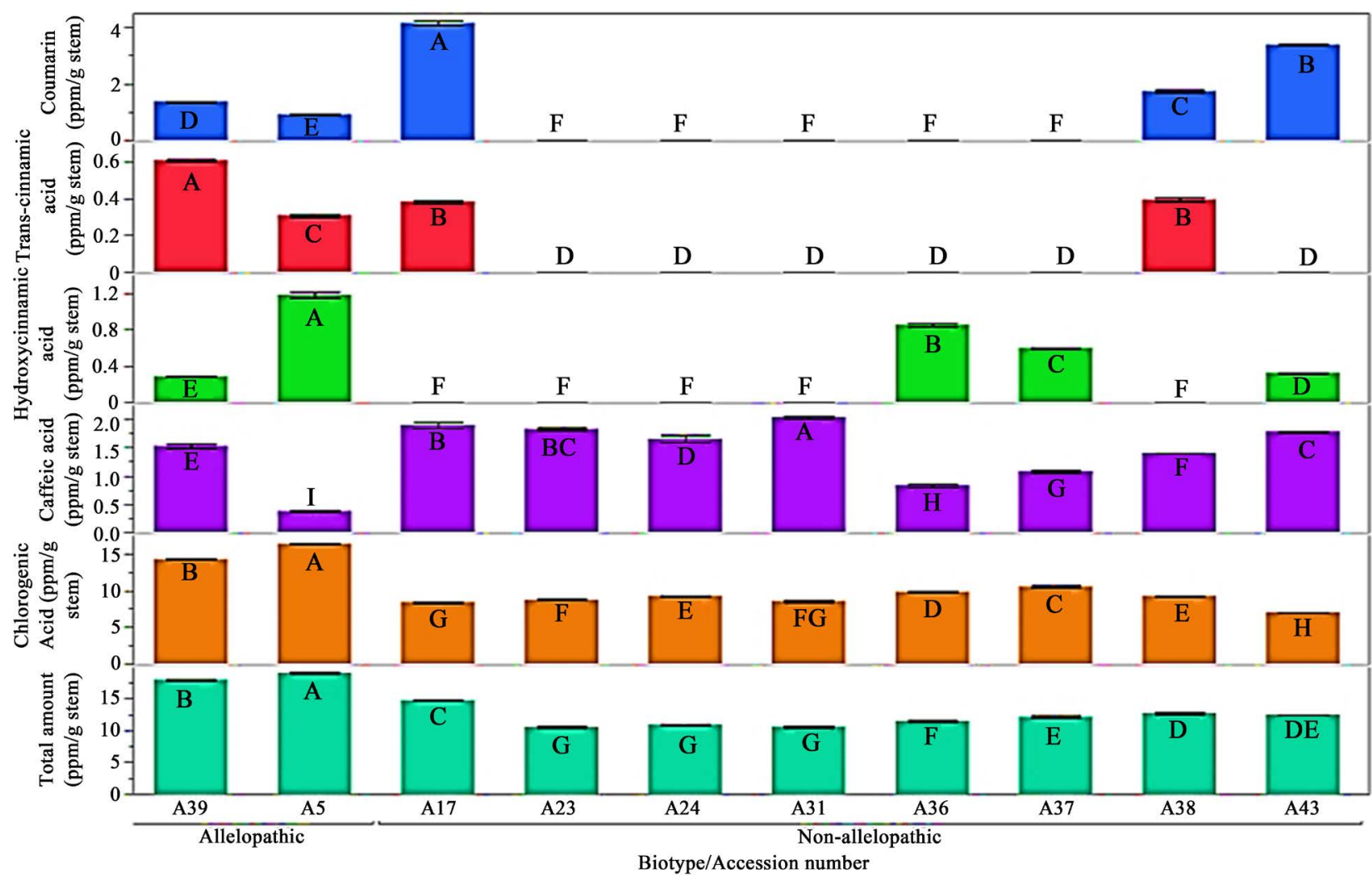

a. Means were separated using Students t-test at $\mathrm{P}<0.05$. Also, means indicated by the same letter do not differ from each other.

Figure 3. Mean comparison of each allelochemical in all sweet potato cultivars.

Table 2. Allelopathic potential of sweet potato cultivars against palmer amaranth.

\begin{tabular}{cccc}
\hline Cultivar & Biomass reduction (\%) & Height reduction (\%) & Average allelopathy (\%) \\
\hline A5 & 39 & 87 & 63.0 \\
A17 & 22 & 71 & 46.5 \\
A23 & 2 & 66 & 34.0 \\
A24 & 21 & 65 & 43.0 \\
A31 & 20 & 75 & 47.5 \\
A36 & 24 & 14 & 19.0 \\
A37 & 22 & 17 & 19.0 \\
A38 & 6 & 77 & 41.5 \\
A39 & 39 & 80 & 59.5 \\
A43 & 26 & 54 & 40.0 \\
\hline
\end{tabular}

weed suppressive potential of $19 \%$. The weed suppressive allelochemicals may be more active in soil because of adsorption to soil colloids and organic matter [33].

The hierarchical clustering of sweet potato cultivars, based on their differences in allelochemical compounds, grouped them into three different clusters (Figure 4). Sweet potato cultivars in each cluster exhibited different levels of weed suppressive potential. Cultivars represented by the same color belong to the same 


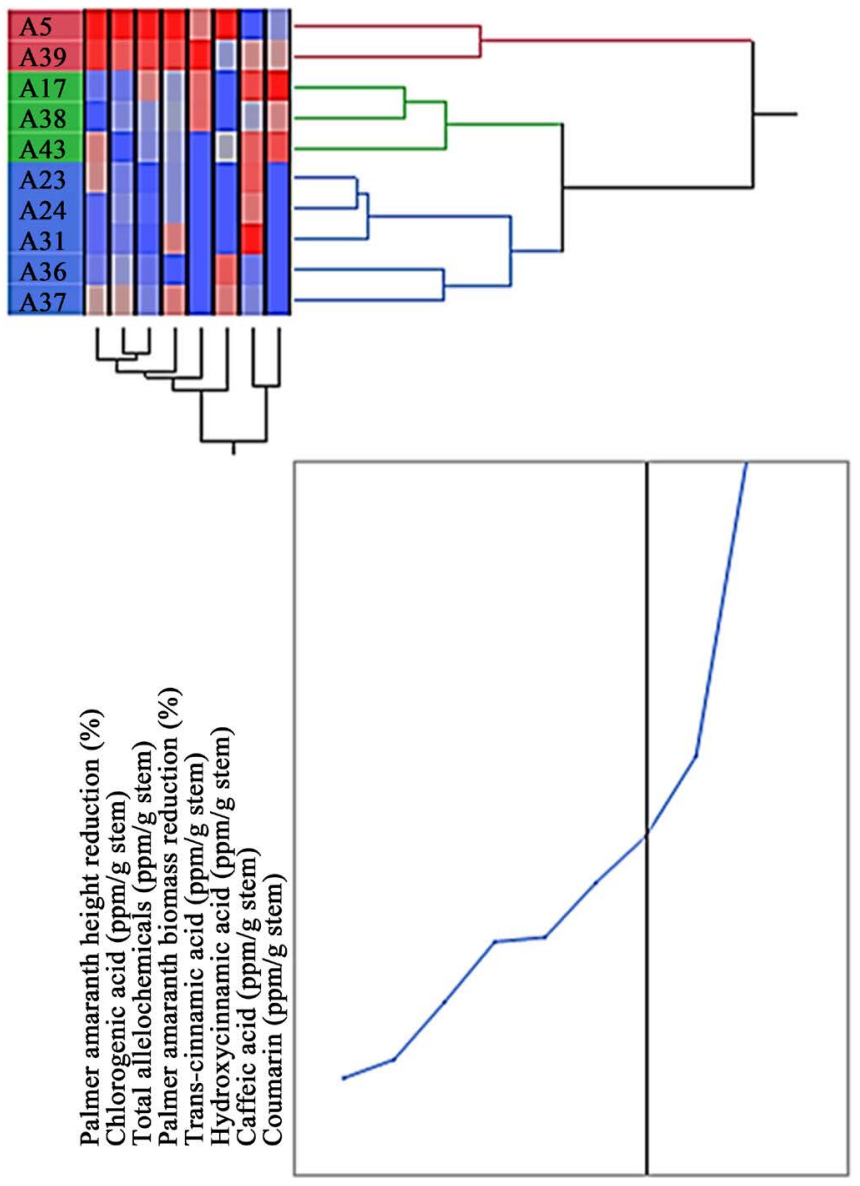

Figure 4. Two-way cluster analysis using all traits.

group. Cluster 1 contained two cultivars (5 and 39) and displayed a high concentration of allelochemicals, which significantly suppressed the height and biomass of palmer amaranth weed. Clusters 2 and 3 were considered as non-allelopathic; however, cultivars 17,38 , and 43 showed intermediate allelopathic potential due to high amounts of coumarin and caffeic acid and did not inhibit the weed growth effectively. Cluster 3 consisted entirely of non-allelopathic cultivars, which showed the least weed growth inhibition. Similar observations were made by Xuan et al. (2016) where they determined that the ability of sweet potato cultivars in suppressing the growth of cogongrass (Imperata cylindrica) is cultivar dependent [34]. In their study, three (Yen 36, 54, and 615) out of 48 cultivars inhibited the germination of cogongrass by more than $90 \%$, thus indicating their high weed germination suppressive potential in contrast to weak germination suppression shown by the rest of the cultivars. Differential allelopathic potential of sweet potato cultivars suggests that these may have different inhibitory compounds or the quantity of these allelochemicals vary among the sweet potato cultivars [35].

Results from the principal component analysis (PCA) indicates that $54 \%$ of the variation was attributed to component 1 , and $25 \%$ of the variation was from component 2 (Figure 5). All parameters used for evaluating allelopathic potential 


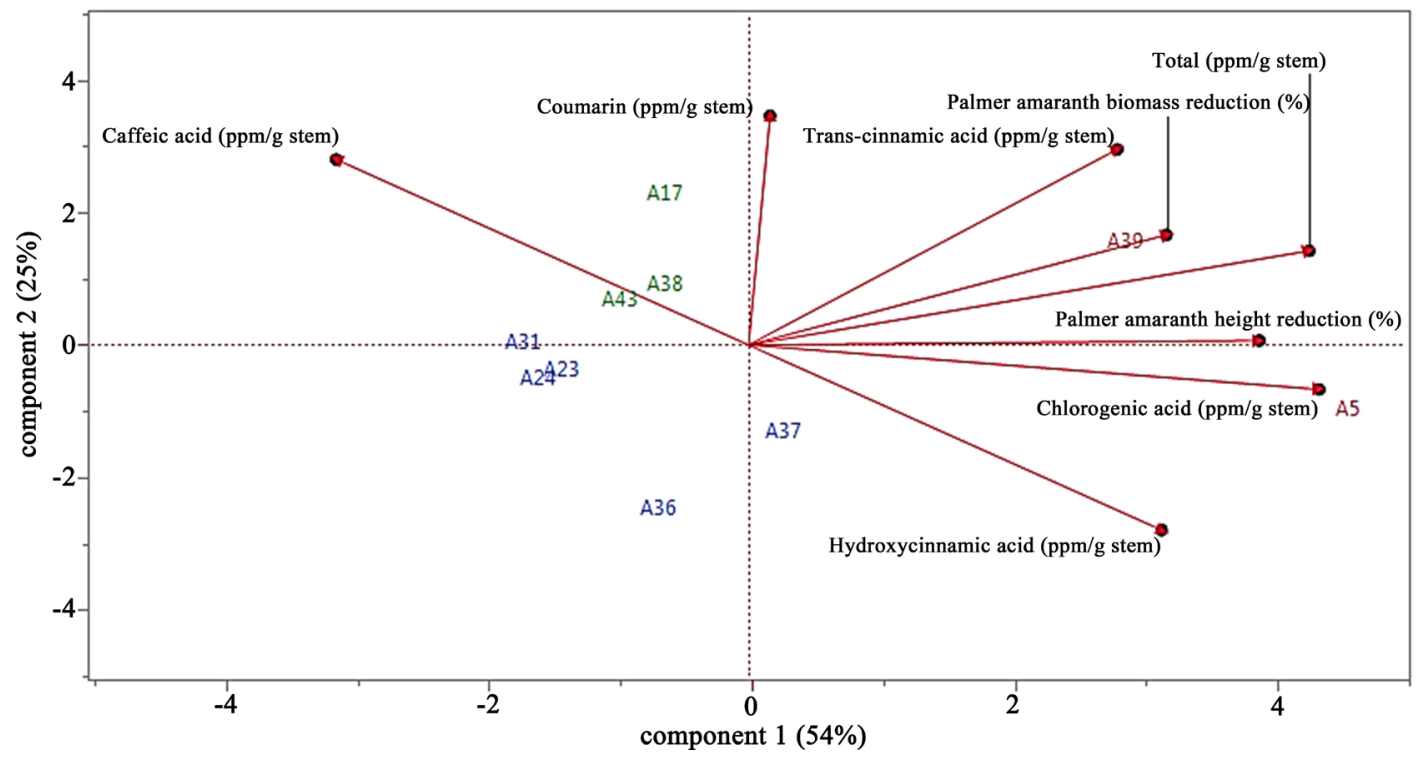

Figure 5. PCA analysis using all traits.

were positively correlated with component 1 . The PCA data correlated with the two-way cluster analysis in which cultivars 5 and 39 showed higher concentration for total allelochemical compounds and effectively reduced the growth of Palmer amaranth weed. Component 2 was grouped distantly, thus indicating that the growth of weeds was not affected by other cultivars. Sweet potato cultivars were also demonstrated to have potential suppressive ability against cogongrass (Imperata cylindrica), bidens (Bidens pilosa), and goatweed (Ageratum conyzoides) weeds by up to $97 \%, 90 \%$ and $85 \%$, respectively [34].

It has been identified that sweet potato contains plant growth inhibitors like coumarin, caffeic acid, and trans-cinnamic acid; however, caffeic acid is influenced by both environmental conditions and the genetic makeup of the plant [24]. Also, the high allelopathic potential of few sweet potato cultivars identified in this study may be due to the difference in their origin which may have influenced their genetic makeup in the long run.

\section{Conclusion}

Based on our methodology and findings, we can conclude that the growth-inhibiting allelochemicals were successfully extracted during root propagation from various sweet potato cultivars, and the HPLC technique was useful in quantifying these allelochemicals. The hierarchical clustering of sweet potato cultivars based on their allelopathic potential against Palmer amaranth resulted in three distinct clusters. Cluster 1 represented higher weed suppressive potential than clusters 2, while cluster 3 consisted of cultivars with non-allelopathic potential. Quantification of allelochemicals in all sweet potato cultivars classified them into two biotypes, allelopathic and non-allelopathic. Two cultivars, A5 and A39, produced the highest amounts of allelochemicals and showed a significant reduction in height and biomass of Palmer amaranth weed species. On the other hand, due to 
the presence of low allelochemicals, some cultivars were able to reduce weed growth by only $19 \%$. The use of allelopathic sweet potato cultivars will reduce the usage of herbicides for weed management, and therefore prevent further evolution of herbicide-resistant weeds. Allelopathic sweet potato cultivars will also be an effective option for managing weeds in organic production as herbicides are not permitted to be used.

\section{Acknowledgements}

This research was funded by the Specialty Crop Block Grant sponsored by the Mississippi Department of Agriculture and Commerce/U.S. Department of Agriculture-Agriculture Marketing Service. Also, it was supported by the National Institute of Food and Agriculture, U.S. Department of Agriculture, Hatch project under cultivar number 230060.

\section{Conflicts of Interest}

The authors declare no conflicts of interest regarding the publication of this paper.

\section{References}

[1] Woolfe, J.A. (1992) Sweet Potato: An Untapped Food Resource. Cambridge University Press, Cambridge.

[2] Service, U.D.o.A.N.A.S. (2007) Census of Agriculture. US Department of Agriculture, Washington DC.

[3] Morgan, K.L., Hood, K.W. and Myles, A. (2012) Mississippi Sweetpotato 2012 Industry Evaluation.

[4] Hoppenstedt, Z.N., et al. (2019) Yield, Quality, and Performance of Organic Sweet Potato Slips Grown in High Tunnel Compared with Open Field. HortTechnology, 29, 140-150.

[5] Meyers, S.L. and Shankle, M.W. (2015) Interference of Yellow Nutsedge (Cyperus esculentus) in "Beauregard" Sweetpotato (Ipomoea batatas). Weed Technology, 29, 854-860. https://doi.org/10.1614/WT-D-15-00019.1

[6] Akobundu, I.O. (1980) Weed Science Research at the International Institute of Tropical Agriculture and Research Needs in Africa. Weed Science, 28, 439-445. https://doi.org/10.1017/S0043174500055648

[7] Kelly, S.T., Shankle, M.W. and Miller, D.K. (2006) Efficacy and Tolerance of Flumioxazin on Sweetpotato (Ipomoea batatas). Weed Technology, 20, 334-339. https://doi.org/10.1614/WT-04-330R1.1

[8] Webster, T. (2014) Weed Survey-Southern States 2014. Vegetable, Fruit and Nut Crop Sub-Section. In: Proceedings of the Southern Weed Science Society 67 th Annual Meeting, Southern Weed Science Society, Birmingham, 288.

[9] Porter, W.C. (1990) Clomazone for Weed Control in Sweetpotatos (Ipomoea batatas). Weed Technology, 4, 648-651. https://doi.org/10.1017/S0890037X00026142

[10] Meyers, S.L., et al. (2010) Interference of Palmer Amaranth (Amaranthus palmeri) in Sweetpotato. Weed Science, 58, 199-203. https://doi.org/10.1614/WS-D-09-00048.1 
[11] Meyers, S.L. and Shankle, M.W. (2016) Postemergence Yellow Nutsedge Management in Sweetpotato. Weed Technology, 30, 148-153. https://doi.org/10.1614/WT-D-15-00032.1

[12] Westberg, D.E., Oliver, L.R. and Frans, R.E. (1989) Weed Control with Clomazone Alone and with Other Herbicides. Weed Technology, 3, 678-685. https://doi.org/10.1017/S0890037X00033030

[13] Meyers, S.L., Jennings, K.M. and Monks, D.W. (2013) Herbicide-Based Weed Management Programs for Palmer Amaranth (Amaranthus palmeri) in Sweetpotato. Weed Technology, 27, 331-340. https://doi.org/10.1614/WT-D-12-00036.1

[14] Rice, E.L. (2012) Allelopathy. Academic Press, Cambridge.

[15] Dadkhah, A. (2015) Allelopathic Potential of Canola and Wheat to Control Weeds in Soybean (Glycine max). Russian Agricultural Sciences, 41, 111-114. https://doi.org/10.3103/S1068367415020081

[16] Kong, C.H., et al. (2011) Breeding of Commercially Acceptable Allelopathic Rice Cultivars in China. Pest Management Science, 67, 1100-1106.

https://doi.org/10.1002/ps.2154

[17] Alsaadawi, I.S., Sarbout, A.K. and Al-Shamma, L.M. (2012) Differential Allelopathic Potential of Sunflower (Helianthus annuus L.) Genotypes on Weeds and Wheat (Triticum aestivum L.) Crop. Archives of Agronomy and Soil Science, 58, 1139-1148. https://doi.org/10.1080/03650340.2011.570335

[18] Dilday, R., Lin, J. and Yan, W. (1994) Identification of Allelopathy in the USDA-ARS Rice Germplasm Collection. Australian Journal of Experimental Agriculture, 34, 907-910. https://doi.org/10.1071/EA9940907

[19] Harrison, H.F. and Peterson, J.K. (2017) Allelopathic Effects of Sweetpotatos (Ipomoea batatas) on Yellow Nutsedge (Cyperus esculentus) and Alfalfa (Medicago sativa). Weed Science, 34, 623-627. https://doi.org/10.1017/S0043174500067552

[20] Peterson, J.K. and Harrison, H.F. (1991) Differential Inhibition of Seed Germination by Sweetpotato (Ipomoea batatas) Root Periderm Extracts. Weed Science, 39, 119-123. https://doi.org/10.1017/S0043174500057970

[21] Taylorson, R. (1967) Some Properties of a Growth Inhibitor in Ipomoea. Proceedings-Southern Weed Science Society, 19, 370.

[22] Rice, E. (1984) Allelopathy. Physiological Ecology. Academic Press, Orlando.

[23] Bonanomi, G., et al. (2006) Phytotoxicity Dynamics of Decaying Plant Materials. New Phytologist, 169, 571-578. https://doi.org/10.1111/j.1469-8137.2005.01611.x

[24] Chon, S.-U. and Boo, H.-O. (2005) Difference in Allelopathic Potential as Influenced by Root Periderm Colour of Sweet Potato (Ipomoea batatas). Journal of Agronomy and Crop Science, 191, 75-80. https://doi.org/10.1111/j.1439-037X.2004.00138.x

[25] Sondheimer, E. (1958) On the Distribution of Caffeic Acid and the Chlorogenic Acid Isomers in Plants. Archives of Biochemistry and Biophysics, 74, 131-138. https://doi.org/10.1016/0003-9861(58)90207-8

[26] Seigler, D.S. (1996) Chemistry and Mechanisms of Allelopathic Interactions. Agronomy Journal, 88, 876-885. https://doi.org/10.2134/agronj1996.00021962003600060006x

[27] Holappa, L.D. and Blum, U. (1991) Effects of Exogenously Applied Ferulic Acid, a Potential Allelopathic Compound, on Leaf Growth, Water Utilization, and Endogenous Abscisic Acid Levels of Tomato, Cucumber, and Bean. Journal of chemical ecology, 17, 865-886. https://doi.org/10.1007/BF01395596 
[28] Sánchez-Moreiras, A., et al. (2004) Mode of Action of the Hydroxamic Acid BOA and Other Related Compounds. In: Macías, F.A., Galindo, J.C.G., Molinillo, J.M.G. and Cutler, H.G., Eds., Allelopathy. Chemistry and Mode of Action of Allelochemicals, CRC Press, Boca Raton, 239-252.

[29] Olmsted III, C.E. and Rice, E.L. (1970) Relative Effects of Known Plant Inhibitors on Species from First Two Stages of Old-Field Succession. The Southwestern Naturalist, 15, 165-173. https://doi.org/10.2307/3670344

[30] Weir, T.L., Park, S.-W. and Vivanco, J.M. (2004) Biochemical and Physiological Mechanisms Mediated by Allelochemicals. Current Opinion in Plant Biology, 7, 472-479. https://doi.org/10.1016/j.pbi.2004.05.007

[31] Keck, R.W. and Hodges, T. (1973) Membrane Permeability in Plants: Changes Induced by Host-Specific Pathotoxins. Phytopathology, 63, 226-230.

https://doi.org/10.1094/Phyto-63-226

[32] Dayan, F.E. and Duke, S.O. (2009) Biological Activity of Allelochemicals. In: Plant-Derived Natural Products, Springer, Berlin, 361-384. https://doi.org/10.1007/978-0-387-85498-4 17

[33] Shettel, N.L. and Balke, N.E. (1983) Plant Growth Response to Several Allelopathic Chemicals. Weed Science, 31, 293-298. https://doi.org/10.1017/S0043174500069034

[34] Xuan, T., et al. (2016) Allelopathic Potential of Sweet Potato Varieties to Control Weeds: Imperata cylindrica, Bidens pilosa and Ageratum conyzoides. Allelopathy Journal, 38, 41-54.

[35] Reinhardt, C., Meissner, R. and Nel, P. (1993) Allelopathic Effect of Sweetpotato (Ipomoea batatas) Cultivars on Certain Weed and Vegetable Species. South African Journal of Plant and Soil, 10, 41-44. https://doi.org/10.1080/02571862.1993.10634641 